REGARDS

SUR L'ECONOMIE ALLEMAND

BULLETIN ECONOMIQUE DU CIRAC
Regards sur l'économie allemande

Bulletin économique du CIRAC

$66 \mid 2004$

Varia

\title{
Modèle rhénan
}

SASSMANNSHAUSEN Günther, Heinz Dürr.Annäherung an einen neugierigen Unternehmer

\section{OpenEdition}

\section{Journals}

Édition électronique

URL : http://journals.openedition.org/rea/3877

DOI : $10.4000 /$ rea.3877

ISBN : 978-2-8218-0828-7

ISSN : 1965-0787

Éditeur

CIRAC

Édition imprimée

Date de publication : 1 mai 2004

ISSN : 1156-8992

Référence électronique

"Modèle rhénan », Regards sur l'économie allemande [En ligne], 66 | mai 2004, mis en ligne le 13 octobre 2009, consulté le 22 septembre 2020. URL : http://journals.openedition.org/rea/3877 ; DOI : https://doi.org/10.4000/rea.3877

Ce document a été généré automatiquement le 22 septembre 2020

(C) CIRAC 


\section{Modèle rhénan}

SASSMANNSHAUSEN Günther, Heinz Dürr.Annäherung an einen neugierigen Unternehmer

\section{RÉFÉRENCE}

\section{SASSMANNSHAUSEN Günther, Heinz Dürr. Annäherung an einen neugierigen}

Unternehmer, Campus Verlag, Francfort/New York, 2003, 324 p.

1 Heinz Dürr (né en 1933) est l'un de ces patrons qui incarnent le «modèle rhénan » par leur parcours et leur engagement social. Après avoir gravi tous les échelons de la PME familiale (équipement automobile), $\mathrm{H}$. Dürr a été président du directoire d'AEGTelefunken, membre du directoire de Daimler-Benz AG, puis, au moment de l'unification, président de la Bundesbahn et de la Deutsche Reichsbahn, dont il a mené à bien la fusion avant de gérer la désétatisation de la nouvelle Deutsche Bahn AG à partir de 1994. Portrait de l'auteur de cette célèbre sentence qui résume le modèle rhénan: «l'entreprise est une manifestation sociale ». (IB) 